\title{
Resensi
}

\section{Meraih Hikmah dibalik Peristiwa Gempa Bumi (Bagaimana Seorang Mukmin Menyikapi Terpaan Musibah)}

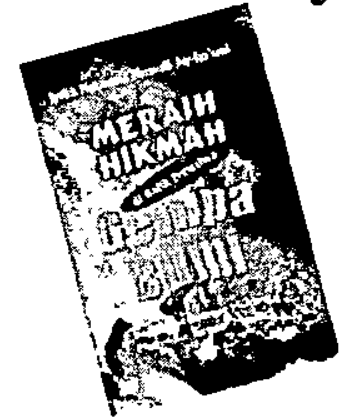

ehidupan manusia tidak terlepas dari dua kondisi yang senantiasa berlawanan, ada siang dan malam ada rasa susah dan rasa senang, yang pada puncaknya manusia dihadapkan kepada fenomena kehidupan dan kematian. Semuanya Allah SWT ciptakan secara berpasangan agar terwujud suatu keseimbangan. Sebagai dar al 'amal, kehidupan dunia ini didalamnya memuat berbagai peristiwa yang menjadi bahan ujian bagi seluruh umat manusia, tentang siapa di antara mereka yang paling baik amal perbuatannya. Sebagaimana firman Allah SWT di dalam Al-Qur'an surat Al-Mulk ayat 2 yang artinya: "Yang telah menjadikan mati dan hidup, supaya Dia menguji kamu, siapa diantara kamu yang lebih baik amainya. Dan Dia maha Perkasa lagi Maha Pengampun."

Ujian yang Allah berikan pada manusia ada dua macam, ujian yang baik dan ujian yang buruk. Ujian yang berupa kesenangan yang disebut ni'mat dan ujian yang berupa kesusahan yang disebut niqmat. Kedua hal tersebut bisa dikatakan ujian bila menimpa orang mukmin, sedangkan keduanya bisa menjadi siksaan bila diterima dan dirasakan oleh orang kafir.

Dalam Islam ada anjuran untuk senantiasa muhasabah al-nafs (mengoreksi diri/jiwa). Untuk mengetahui setiap kejadian yang menimpa terhadap diri seseorang apakah itu merupakan ujian atau siksaan yang Allah SWT berikan kepadanya. Ketika seseorang sedang berusaha untuk senantiasa mendekatkan disi kepada Allah Rabbul 'Izzati dengan berbagai aktifitas ibadahnya, ia bisa menyimpulkan bahwa musibah yang menimpa adalah ujian terhadap keimanannya. Sebaliknya, seseorang yang tidak pernah mau mengenal Allah SWT sebagai Tuhan Sang Penguasa, beranggapan bahwa musibah yang menimpanya adalah siksaan didunia yang Allah berikan sebagai peringatan kepadanya agar kembali kejalan yang benar.

Banyak sekali jenis ujian dan siksaan yang Allah berikan kepada manusia, baik yang mengenai fisik, materi, maupun yang menggoncangkan jiwa, entah itu berupa penyakit, bencana sosial maupun bencana alam. Dalam kaitan ini akan diungkap hikmah yang terkandung dalam Peristiwa Gempa Bumi, sebagai resensi dari sebuah 
buku yang berjudul: "Ash-Shabru Indal Mushibah", yang ditulis oleh Syeikh Muhammad Mutawalli Asy-Sya'rawi. Buku tersebut diterjemahkan kedalam bahasa Indonesia oleh: Ahmad Sunarto, dengan judul: "Meraih Hikmah di Balik Peristiwa Gempa Bumi, Bagaimana Seorang Muslim Menyikapi Terpaan Musibah". Buku tersebut merupakan hasil ungkapan perasaan penulisnya dalam menyikapi fenomena alam semesta, khususnya gempa bumi yang amat dahsyat yang terjadi di Mesir pada tahun 1992. Dalam buku tersebut, penulis berusaha mengungkapkan gejala kerusakan alam tersebut dengan kaca mata nilai-nilai ilahiyah (teologis) dengan terlebih dahulu mengemukakan makna gempa bumi secara terminologis dan pemahaman secara geologis. Kemudian dimuat juga di dalamnya, peristiwa-peristiwa masa lalu tentang berbagai fenomena alam yang menakjubkan, dan dikemukakan tentang segala kemungkinan yang akan terjadi di alam semesta sehingga menimbulkan kesadaran akan keharusan untuk senantiasa mendekatkan diri kepada Allah SWT.

Dalam buku ini penulis memulai pembahasannya dengan mengemukakan terminologi gempa bumi dan kaitannya dengan gejala fenomena alam yang lain.

Dalam pembahasannya, penulis lebih mengarahkan dan menggiring terhadap makna lughawy (kebahasaan) dengan cara membandingkan antara makna zalzalah (hal.9) (goncangan) dengan makna mailah (kecenderungan). la hanya sedikit mengungkapkan makna gempa bumi tersebut dengan kaca mata sain dan teknologi tentang gejala alam atau pendekatan geologis (hal.11). Demikian juga ilustrasi lain yang dikemukakan, seperti adanya peristiwa berubahnya lautan menjadi daratan dan gunung ketika Allah SWT memper- lihatkan mukjizat nabi Musa as dan sifat api yang berubah menjadi dingin dan menyelamatkan, ketika terjadi pembakaran nabi Ibrahim as oleh raja Namrud. Dalam kaitan inilah penulis mengungkapkan bahwa gempa bumi adalah fenomena alam yang tidak dapat diperkirakan kapan terjadinya, karena ia keluar dari ketetapan peraturan semula sehingga tidak dapat diperkirakan oleh ilmu pengetahuan dan apabila terjadi maka tidak seorangpun dapat mencegahnya atau menghindarinya.

Setelah mengemukakan makna gempa bumi, penulis mengulas tentang bagaimana Menyikapi gempa bumi dengan pendekatan spiritual.

Untuk menggugah perasaan batiniyah, penulis memulai dengan himbauan untuk bertaubat menjelang kematian dengan ilustrasi kisah Fir'aun yang tidak diterima taubatnya karena ia bertaubat pada saat detik-detik kematian sudah datang. Idealnya, seorang muslim itu harus selalu sadar bahwa kematian senantiasa mengintai sehingga ia terus berusaha untuk berbuat amal yang baik agar di saat akhir hayatnya ditutup dengan husn al-khatimah. (hal.25)

Gambaran peristiwa hari kiamat yang sangat dahsyat sehingga seseorang sudah tidak mengingat siapa-siapa lagi termasuk keluarganya, pada saat itu manusia panik dan berusaha untuk menyelamatkan dirinya masing-masing. Seorang ayah tidak mengingat lagi anaknya, begitu juga sebaliknya. (hal.28,29)

Adanya kaitan erat antara bencana alam yang terjadi dengan kerusakan moral/akhlak disuatu negeri., dalam bahasan ini, penulis menyoroti masalah kerusakan sebuah bangunan yang diakibatkan tidak seimbangnya konstruksi bangunan tersebut karena dalam proses pembangunannya sang pengelola menyalahgunakan (mengo- 
rup) dana untuk pembiayaan bangunan tersebut. (hal 31,32 ).

Memahami gempa bumi dengan pendekatan prasangka baik (khusnu aldzan) dan adanya keharusan berdakwah bagi umat Islam, karena musibah/siksa yang diturunkan Allah SWT tidak hanya menimpa orang-orang yang salah dan berdosa saja melainkan orang yang saleh dan berjasa juga akan terkena getahnya, akibat kelalaian mereka dalam menyampaikan ajaran Islam kepada saudaranya sesama umat Islam. (hal 33,35-46).

Keadaan semacam itu dialami juga oleh umat islam. Sebagian orang diantara kita mengetahui adanya berbagai kemunkaran yang dilakukan oleh saudarasaudara kita, tetapi, mereka tidak menasehatinya, apalagi memperingatkannya. Sehingga, tidak jarang diantara orang-orang baik yang tewas bersama para pelaku dosa, bila terjadi suatu malapetaka. Sebaliknya, kalau orang-orang baik diantara kita berani memberi nasehat kepada para pelaku dosa, apalagi kalau berani mencegah kejahatan mereka, pasti Allah tidak mudah menurunkan malapetaka kepada umat Islam. Bukankah, para ulama dan Rasulullah saw pernah memberi perumpamaan kepada kita tentang sejumlah orang yang naik kapal. Diantara mereka ada yang naik di bagian atas dan ada pula yang naik dibagian bawah. Mereka yang berada di bagian bawah selalu mendapat air dari mereka yang berada di bagian atas. Sehingga mereka ingin mendapat air secara langsung. Karena itu, mereka ingin melubangi kapal tersebut agar mudah mendapat air.

Pelajaran yang dapat diambil dari perumpamaan tersebut adalah masyarakat Islam ini bagai para penumpang kapal. Diantara mereka ada orang-orang yang baik dan ada pula yang tidak. Jika orang-orang baik tidak pernah menasehati atau mencegah kemunkaran yang suka dilakukan oleh para pelaku dosa, tentunya kalau Allah menurunkan malapetaka, pasti semua ikut terkena dampak negatifnya. Sebaliknya, kalau ada yang mencegah kejahatan yang suka dilakukan oleh para pelaku dosa, pasti Allah menyelamatkan orang-orang yang baik.

Definisi Iman dan sikap seorang muslim dalam menghadapj musibah yang menimpa dirinya dengan cara mengambil hikmah dibalik peristiwa tersebut, dengan ilustrasi kisah nabi Khidhir as. yang merusak sebuah perahu, karena ia mengetahui hakikat peristiwa yang akan terjadi sesudahnya.

Bagi seorang muslim, cobaan merupakan sarana untuk mengutarakan kepasrahan dirinya kepada Allah dan menunjukkan kelemahannya, karena ia yakin bahwa tiada daya dan kekuatan, kecuali setelah mendapat ijin dari-Nya. (hal.47-55)

Kaitan gempa bumi dengan keadaan jiwa seseorang, bila ia bersabar akan musibah tersebut, maka ja akan mendapat kemenangan dan ridha Allah SWT. Besamya cobaan yang diterima Rasulullah SAW jauh lebih berat dibandingkan dengan cobaan yang menimpa manusia lainnya, tetapi beliau senantiasa bersabar dan berlapang dada bahkan beliau selalu berdoa untuk kebaikan orang yang akan mencelakakan beliau, Contohnya ketika beliau mendatangi kampung Thaif, bukannya sambutan yang baik melainkan sambitan yang beliau terima, tetapi beliau tetap sabar bahkan berdoa agar Allah SWT memberikan hidayah kepada mereka. (hal.60-91)

Keberadaan korban gernpa bumi dapat dikategorikan orang-orang yang syahid apabila saat kematiannya membawa iman. Sebaliknya, bagi mereka yang selamat 
hendaklah menyadari bahwa hal tersebut. semata-mata kekuasaan Allah SWT. Dengan ilustrasi, kisah selamatnya nabi Musa as. sewaktu masih bayi dari kekejaman Fir'aun. (hal.101-112)

Orang-orang yang tertimpa gempa bumi, maka mereka mendapat pahala sebesar iman mereka terhadap qadha dan taqdir Allah. Ketika ia menghadapi cobaan dengan sabar dan berharap pahala Allah, maka ia akan mendapat pahala dan kerugiannya akan diganti oleh Allah. Misalnya seseorang yang kehilangan pandangan matanya karena gempa bumi, maka apa yang akan ia peroleh jika ia bersabar? Jawabnya, dalam sebuah hadits sahih Anas ibnu Malik menuturkan bahwa Rasulullah saw. Bersabda yang artinya:"Jika seseorang diuji oleh Allah dengan lenyapnya salah satu pandangan matanya dan ia bersabar, maka Allah akan menggantikannya dengan surga."

Dalam riwayat lain disebutkan bahwa Allah berfirman yang maksudnya: "Jika Aku memngambil pandangan kedua mata hambaKu ketika di dunia, maka ia tidak mempunyai balasan apapun di sisi-Ku selain surga."

Hadits di atas merupakan contoh terbaik bagi siapapun yang tertimpa malapetaka, kemudian ia bersabar. Demikjan pula, mereka yang tertimpa gempa bumi, maka kejadian itu merupakan ujian dari Allah untuk menguji keimanan, ketawakalan dan kesabaran mereka.

Seorang yang beriman jika tertimpa malapetaka atau saudaranya yang tertimpa malapetaka, pasti ia berkata kepadanya: "Engkau hanya mengetahui malapetaka yang menimpa kepadamu, tetapi engkau tidak mengetahui balasan apa yang disediakan oleh Tuhanmu."

Kiat melindungi diri dari bencana dengan cara berikhtiar mencari tempat yang aman dengan disertai keimanan terhadap Allah SWT. Dengan ilustrasi diantaranya peristiwa sahabat Umar bin Khattab ra. Ketika menghindari tha'un. (hal.113-125).

Penyerahan diri kepada Allah SWT dengan cara berdoa dan istighfar adalah cara yang baik menghadapi musibah. Seorang muslim yang baik, ia akan senantiasa berdoa baik dalam keadaan tenang dan aman maupun ketika musibah datang menimpanya. (hal.126-132).

Dari hasil karya tulis tentang gempa bumi ini, terkesan adanya kegelisahan yang dirasakan oleh sang penulis, bahwa penulis berusaha memahami fenomena gempa bumi tersebut dengan pendekatan spiritual sebagai gajala alam yang biasa dan bisa terjadi kapan dan dimana saja sesuai dengan kehendak Allah SWT. Tetapi ia kaitkan dengan adanya perilaku manusia yang menempati bumi ini. la juga menangkap adanya kelalaian manusia dalam kesadaran ketika menerima musibah. Dengan berbagai ilustrasi yang bersumber dari Al-Qur'an dan Hadits Nabi, ia berusaha meyakinkan pembaca agar memahami musibah sebagai peringatan dari Allah SWT.

Karena latar belakang penulisan adalah peristiwa gempa bumi yang terjadi di Mesir yang menghancurkan beberapa bangunan di sana, ia mencoba mengajak pembaca untuk menyadarkan mereka akan bahayanya korupsi. Salah satu faktor penyebab runtuhnya bangunan tersebut karena dana pembangunannya dikorup oleh para pengelolanya pada waktu itu. Penulis merasa khawatir terhadap kaum muslimin yang tidak mampu menerima cobaan dengan datangnya musibah dari Allah SWT.

Kajian terhadap topik ini sangat menarik mengingat akhir-akhir ini di negeri kita juga banyak mengalami hal yang sama 
yaitu adanya bencana gempa bumi, banjir dan tsunami. Apabila buku ini dibaca secara tuntas, diharapkan pembacanya mampu merenungkan makna-makna musibah yang terjadi di Indonesia. Selama ini tidak sedikit dari saudara-saudara kita yang masih memahami bencana yang terjadi sebagai kerusakan alam semata, mereka tidak melihatnya dari kaca mata spiritual dan keimanan sehingga dapat menumbuhkan kesadaran akan pentingnya ibadah dan menjaga lingkungan hidup di sekitar kita. Dengan membaca buku ini, kita diingatkan untukmenyadari akan kekeliruan-kekeliruan kita selama ini dalam menjalankan tugas sebagai Abdi Allah dan sebagai Khalifatullah fial-ardh.

Sebagai sumbang saran atau kritikan kecil, dalam penulisan buku ini kurang sistematik dalam menempatkan urgensi permasalahan, sehingga terkesan meloncatloncat dari pembahasan yang satu ke pembahasan yang lainnya dan tidak adanya kesinambungan antara materi pembahasan dengan materi sub pembahasan. Sebaiknya, pada buku tersebut penulis terlebih dahulu membahas definisi gempa bumi secara mendetail, kemudian masuk ke ilustrasi-ilustrasi yang lain berupa peristiwaperistiwa bencana yang terjadi di masa lalu, setelah itu dikaitkan dengan nilai-nilai keimanan, keilmuan dan akhlakul karimah dengan figur sentral nabi Muhammad SAW, juga para nabi yang lain dan orang-orang yang beriman, setelah itu baru masuk ke pembahasan mengenai himbauan untuk menyikapi fenomena alam tersebut dengan landasan kesadaran spiritual, bahkan tidak ada salahnya apabila disinggung juga di dalamnya nuansa-nuansa intelektual dari fenomena alam tersebut sehingga buku tersebut bisa memiliki nilai lebih (added value) bagi kesempurnaan keilmuan dan keimanan.

Setelah memahami makna kandunagn dari buku yang ditulis oleh Syeikh Muhammad Mutawalli Asy-Sya'rawi ini dapat disimpulkan bahwa buku kecil ini lebih cocok untuk dibaca sebagai bahan konsumsi nilai-nilai spiritual pembacanya dan kurang pas apabila dikhususkan untuk konsumsi nilai-nilai intelektual karena didalamnya tidak terdapat teori-teori atau konsep-konsep baru yang mampu merangsang geliatnya syaraf-syaraf intelektual. Buku ini lebih cenderung mengajak pembacanya untuk melihat fenomena alam dengan kaca mata hati sehingga mampu menyikap nilai-nilai hikmah yang terkandung di balik musibah apapun yang terjadi.

(Amir Mu'allim) 